\title{
Úlcera de presión por prótesis peneana
}

\author{
A. Palacios, J. Soares, P. Massó, R. Versos, F. Marcelo \\ Servicio de Urologia. Hospital Geral de Santo António. Porto. Portugal.
}

Actas Urol Esp 2006; 30 (2): 237

\begin{abstract}
A.S.C de 78 años de edad, portador de prótesis Apeneana, acude a Urgencias por úlcera de aspecto necrótico localizada en el glande y que produce estenosis parcial del meato urinario externo.

Fue introducida una sonda de Foley y seguido de exéresis completa de la lesión con buenos márgenes quirúrgicos. El estudio histológico reveló lesión benigna.

Pasado un mes se produce exteriorización espontánea de la prótesis de pene. Actualmente el paciente se encuentra asintomático y con buena regeneración del tejido del glande.
\end{abstract}

A. Palacios Hernández

e-mail: aphmmx5@hotmail.com

(Trabajo recibido el 5 de septiembre 2005)

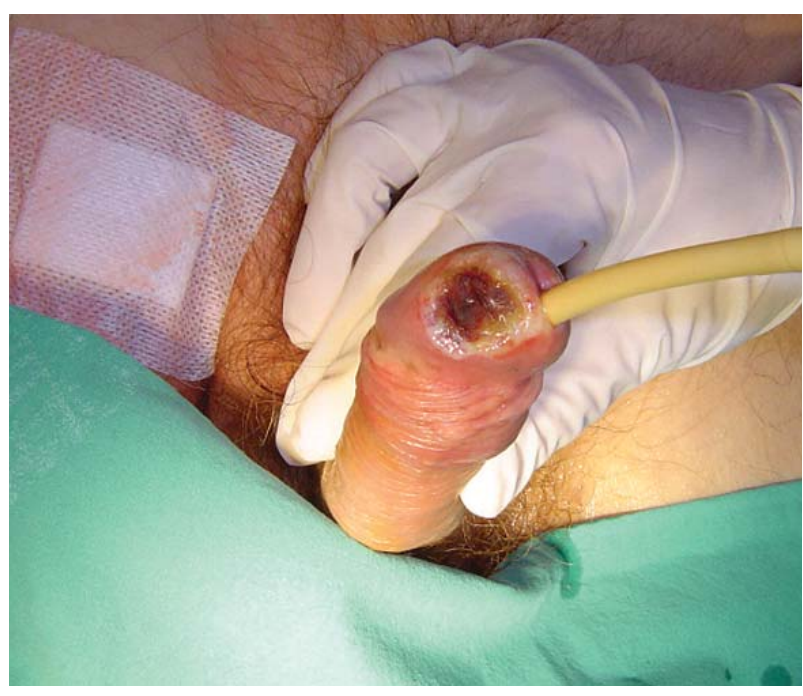

FIGURA 1 